\title{
Composing the social factory: an autonomist urban geography of Buenos Aires
}

\begin{abstract}
Through the creation of an original theoretical framework this paper demonstrates the value of a deeper engagement between autonomist Marxism and (urban) geography. By spatialising arguably the autonomists' key theoretical contribution - class composition - the paper develops the ideas of technical and political spatial compositions. These dialectically intertwined concepts provide a framework with which to analyse the relationships between shifting urban spaces and struggles, and clarity is therefore added to another key autonomist concept, the evocative yet nebulous 'social factory'. Applying these to Buenos Aires, the paper focuses on various spatial conjunctures, exploring their emergence and the immanent potentials for radical spatial politics they afford and preclude. In particular, the paper provides a detailed reading of the complex role Buenos Aires' 'informal' settlements play in both perpetuating and resisting a neoliberal, financially-extractive economy. The benefit of a 'spatial composition' framework is twofold: it provides a periodising heuristic with which to originally and usefully approach urban struggles, and, in unpacking the 'social factory', it can be applied widely as a form of radical geographical praxis. The paper thus makes important theoretical and empirical contributions to an exciting, emerging autonomist (urban) geography as well as to studies of Buenos Aires.
\end{abstract}

\section{Key words}

Autonomist Marxism, Buenos Aires, social factory, class composition, spatial composition

\section{Introduction}

Despite a resurgence across the social sciences (e.g. Shukaitis, 2016; Woodcock, 2017; Wright, 2017), autonomist Marxist thought remains underexplored within contemporary geography. Although some work gestures towards its explanatory, geographical potential (e.g. Gray, 2018; Marks, 2012), the underlying spatiality of autonomist Marxism remains untapped (Toscano, 2004). Through a focus on Buenos Aires' mutating urban form this paper rectifies this. The concepts of technical and political spatial composition are introduced and developed into an original theoretical framework; one that can provide detailed understandings of the 
relationships between urban struggles and the production of urban spaces. In this sense a 'spatial composition' framework can help demystify, and ultimately mobilise, the inherently, yet inchoately, spatial 'social factory'. Specific focus is placed on particular spatial conjunctures, exploring how and why they have emerged, and the potentials for spatial politics that they both afford and preclude - from inspiring experiments in autogestion to the lethal practices of Argentina's military dictatorship. By illustrating the rich geographical potential of an autonomist Marxist 'socio-spatial dialectic' (cf. Soja, 1980), the paper therefore a makes series of clear and important contributions. First, it emphasises the importance of a (re)engagement with autonomist ideas, illustrating how the more common geographical uptake of post-autonomist concepts (see de Bloois et al., 2014; Purcell, 2012) has led to imprecision and the neglect of powerful tools with which to understand capitalism's multiple, intersecting antagonisms (cf. Pitts, 2018). Second, it shows how autonomist thinking can contribute to recent work on dialectical geographical analyses (e.g. Charnock, 2010, 2014), concomitantly developing autonomist ideas themselves. And third, the tracing and development of a nascent autonomist geography enriches debates around the broader idea of autonomous geographies (Pickerill and Chatterton, 2006; Merrifield, 2011; Vasudevan, 2015). And while this original theoretical framework is applied here to Buenos Aires, it is argued that it has far-reaching potential, while crucially remaining true to the autonomist's commitment to fine-grained praxis. Important empirical contributions are also made through a detailed reading of the intersectional and spatial class formations in Buenos Aires' 'informal' urban settlements.

The paper begins by introducing the key autonomist concepts of technical and political class composition. Following this, the related ideas of re- and de-composition are explored, before some limitations of class composition analysis are acknowledged and responded to. With these in mind, the latent spatiality of autonomist thought is unpacked and developed. In particular the ideas of technical and political composition are applied to urban space, creating a framework with which to analyse the relationships between urban struggles and shifts in the urban form. The ways in which capital and the state construct urban space (technical spatial compositions) is never neutral, rather reflective of antagonistic and intersectional class relationships. Technical spatial compositions simultaneously seek to maximise their disciplinary and accumulative potential. But their power is never absolute, and 
thus forms of urban struggle (political spatial compositions) are immanent to prior technical spatial compositions: the interplay between technical and political spatial composition therefore unfolds in an openly dialectical manner. Once developed, this framework is applied to Buenos Aires, tracing the city's shifting urban form. Accordingly, the paper shows the changing spatial repertoires that emerge from Buenos Aires' various periods of spatial de-and re-composition, reflecting that compositional thinking's periodising capacities are extended when spatialised. Finally, particular focus is placed on Buenos Aires' villas miseria (urban 'informal' settlements). Home to large migrant populations, the villas are not only sites of prefigurative, territorial resistance (Sitrin, 2012; Zibechi, 2012), but, in a period of expanded, financial extractivism, have also become metropolitan-circuits through which neoliberalism is (re)produced 'from below' (Gago, 2017): in this dual-sense they epitomise the 'social factory'. The paper explores a socio-spatial dialectic, where intersectional, migrant class struggles shape urban space and vice-versa, thus demonstrating the power and originality of spatial composition analysis.

\section{Class composition}

Autonomist Marxism emerged from the Italian 'workerist' movement of the 1960/70s, with the concept of 'class composition' arguably its most important contribution (Wright, 2017). Central to the project was the belief that, until then, Marxist analysis had overly focused on capital's composition. This had two main consequences: a problematic lack of analysis of the proletariat (Mohandesi, 2013), and a simultaneous reification of capital to a position of omnipotence (Cleaver, 2000). In response Tronti (1964: 89) proposed a 'Copernican inversion' of the dialectic:

\footnotetext{
We...have worked with a concept that puts capitalist development first and workers second. This is a mistake. And now we have to turn the problem on its head, reverse the polarity, and start again from the beginning: and the beginning is the class struggle of the working class.
}

Guided by this and a 'heretical reading' of Capital (Dyer-Witherford, 2008), the autonomists subverted the concepts of capital's technical and organic composition, applying them to the proletariat as technical and political composition - as Thorburn (2017: 55) describes the terms: "class composition highlights a division... between the organisation of labour power by 
capital (the technical composition) and the organisation of the working class against capital (the political composition)."

The real importance, however, lies not in the categories themselves, but in their relationship (Roggero, 2010). Rather than a simple, causal linkage between technical and political compositions, they are (openly) dialectically related (Mohandesi, 2013). Tronti's Copernican inversion is important as shifts in technical compositions are responses by capital to militant political compositions, which affect future political compositions, and so on - shifts from Taylorism to Fordism to post-Fordism and beyond can be understood thusly. At each conjuncture, new formations of capitalism (technical compositions) are developed, in part, to discipline and combat labour unrest (political compositions), ultimately maximising capital accumulation. However, new regimes' disciplinary power is never total, always containing new opportunities for resistance, as "the new antagonistic subjectivity [political composition] is imminent [sic] to the [technical] composition" (Roggero, 2010: 205). Returning to Italy, attempts to combat unions and individual skilled workers under Fordism begat the postFordist 'mass worker'. But as this de-skilling blocked one avenue of struggle, another opened. Extreme alienation and precarity, perhaps counterintuitively, fostered mass 'strategies of refusal' like walk-outs, wildcat strikes, and sabotage (Wright, 2017).

Useful here are two further terms associated with class composition analysis: class reand de-composition. Recomposition represents increasing "concordance of actions across a widening diversity of the class" (Marks, 2012: 470) through "the overthrow of...division, the creation of new unities between sectors of the class, and an expansion of the boundaries of what the 'working class' comes to include" (Zerowork Collective, 1975: 4). This recomposition is caused by the 'circulation of struggle' across the class's geographical and social diversity (Shukaitis et al., 2007: 111). Importantly these struggles can, and do, emerge unexpectedly and separately, often taking place independently from traditional organs of working-class power (Cleaver, 2000). Decomposition is the opposite. It represents increasing weaknesses, divisions, and contradictions among the class which slows down the circulation of struggles (Marks, 2012: 470). Taking up the Italian example again, while the decline of the unions and party immediately led to decomposition, the later upsurge in militancy and recomposition came from non-traditional sources, such as students and southern migrants to the industrial north. While surprising to some, the newfound power of such subjectivities (the political 
composition) reflected, and was immanent to, the economic organisation of the time (the technical composition).

Class composition analysis thus provides a dialectical, periodising heuristic that shuns closure and teleology. Further, given the autonomists' commitment to praxis, it is also a grounded, empirical way to study changing patterns of struggle (Dyer-Witherford, 2008), with the interrelated goals of understanding the proletariat's ever-changing political subjectivities and locating capital's weak points (Wright, 2017). It focuses on different stages of capitalism's specificities, and how these distinct methods of accumulation shape, but, crucially, do not and cannot fully explain resistance/oppression: while technical compositions are important, the 'radical subjective becoming' of the political composition is privileged as "the basis of analysis and political strategy" (Shukaitis, 2013: 656).

Early class composition analyses did, however, overlook key issues such as social reproduction's centrality to recomposition (Thorburn, 2017), and responding to this, recent work has proposed that 'social composition' complements technical and political compositions (Notes From Below, 2018). Relatedly, the role of non-class structures/identities were neglected, which is problematic as capital preys upon divisions to fracture and control workforces, shaping technical compositions (Marks, 2012). But as Camfield (2004) notes, class identities and struggles are never only about class, with other structures/identities central to all political compositions, contributing variously to both de- and re-composition. Class composition analysis must therefore be intersectional (Clare, 2015). Expanded accordingly class composition analysis is a powerful tool. Yet there has been very little explicitly geographical engagement with the concept (cf. Gray, 2015, 2018; Marks, 2012), surprising given autonomist ideas' 'exquisite' yet latent spatiality (Toscano, 2004). It is important to combat this, and the next section therefore develops these ideas, highlighting the mutually beneficial nature of an emergent autonomist geography.

Furthermore, new readings of well-worn concepts are at the heart of the autonomist project, with Battagia (1981: 77) arguing that "the best way to defend workerism today is to go beyond it". This has been done productively by applying autonomist thought to nonEuropean space-times - for instance exploring migrant struggle in Thailand has added nuance to the idea of recomposition (Campbell, 2018), and work in China has helped develop 
approaches to the circulation of struggles (Marks, 2012). Potentially most exciting, however, has been the use of autonomist ideas in a Latin American context (e.g. Gago, 2017), and thus this paper positions itself within a broader current of work which "puts in dialogue two of the most intriguing trends in social and political theory: Italian autonomism and Latin American decolonial thinking" (Luisetti et al., 2015: 1). Removing autonomist thought from its comfort zone is thus an important task, and in this vein Steve Wright (2017: 211) concludes his seminal history of autonomist Marxism by noting that:

[h]aving helped to force the lock...obstructing the understanding of working-class behaviour in and against capital, only to disintegrate in the process, the workerist tradition has bequeathed to others the task of making sense of those treasures which lie within.

Spatialising class composition analysis and applying it to Buenos Aires attempts just this.

\section{Fragments of an autonomist geography}

Autonomist thinking's implicit spatiality is best illustrated by the 'social factory' (Tronti, 1971). Linked to social reproduction, Fordism's demise, and real subsumption extending beyond immediate sites of production, the idea recognised that the 'factory' (representing capitalist forms of control) transcended its own walls (Gray, 2018). This immediately emphasises capitalism's spatiality, and how capital (and thus class struggle) infiltrates all aspects of life (Dyer-Witherford, 2008). This therefore expanded technical composition's purview, and accordingly the political composition of the 'socialised worker' emerged (Day, 2002). As capital penetrated the social fabric, resistance outside of the factory became part of class struggles (Shukaitis and Figiel, 2013), and so changing compositions fostered new political subjectivities and possible recomposition (Dyer-Witherford, 2008).

The spatiality of these processes is exemplified, once more, by Italian struggles. The aforementioned 'mass-worker'-led upsurge in militancy drew a reaction from capital, with shifting technical compositions increasing unemployment. The workplace, for many, therefore lost its salience as a site of struggle. But in its place, the 'socialised worker' targeted capital's circulation and reproduction. Specifically, the group 'Lotta Continua' (The Struggle Continues) emphasised the need to 'take over the city', and new forms of 'territorial community activism' emerged (Gray, 2018). These included rent strikes, squatting, and 
occupations which featured communal, typically women-led, day-care, health clinics, and kitchens. This socially-reproductive, territorial activity contributed to class recomposition, and illustrates that political compositions must also be considered spatially. But contemporaneous analysis of the social factory through this 'reconquest of city centres' (Bologna, 2007: 43) was insightful yet incomplete. The growing circulation of (urban) struggles had a clear geography, but spatial analyses themselves were left wanting.

Work on the social factory from autonomist thinkers typically approached it from a political-economic, rather than a spatial, perspective (Palazzo, 2014), meaning the concepts' inherently geographical nature was underexplored. ${ }^{1}$ Exacerbating this was the term's general imprecision (Pasquinelli, 2014). Tronti's initial formulations saw the social factory representing increasing state control over (urban) society to maximise extraction of surplusvalue (Campbell, 2018). This important insight was taken on most powerfully and cogently by autonomist feminists who demonstrated the vital role of unpaid domestic labour in capital's reproduction (Federici, 2012). But Negri pushed the idea further and, with an attachment to immaterial labour, viewed it as not just the real, but the total, subsumption of life to capital - to express this key difference: "in Tronti society becomes a factory. Life becomes like work. But in Negri, the factory becomes social. Work becomes more like life" (Pitts, 2018: 152). Paradoxically, with such total subsumption resistance becomes both inevitable and impossible. This plane of total immanence stymies as much as it liberates, swapping the focus on specificity and antagonism central to earlier autonomist writing, for the more overarching analyses found in much post-autonomist ${ }^{2}$ work (Bellofiore and Tomba, 2017). This trajectory is a familiar story however (Pitts, 2018: Chapter 6), and something that Wright (2017: 208) flags as a weakness to elements of (post)autonomist thought, given its:

penchant for all-embracing categories that, in seeking to explain everything, too often would clarify very little. Amongst them, that of the social factory always alluded to a significant rethinking of the process of class composition, yet rarely seemed to deliver on its promises.

\footnotetext{
${ }^{1}$ Some early attempts to combat this can be found in the 1970s autonomist journal Quaderni del Territorio (see Negri, 2018).

${ }^{2}$ For an overview in the similarities and differences between autonomist and post-autonomist work see: de Bloois et al., 2014; Bowring, 2004; Wright, 2017.
} 
Yet, in class composition analysis autonomist thinking has precisely the tool to realise the social factory's potential, but only if properly spatialised. Autonomist thinking is at its best when its seeks to go beyond itself, but resists straying into the appealing, yet ultimately frustrating, domain of post-autonomism (Pitts, 2018) - especially pertinent given geography's proclivity to draw from the latter tendency (de Bloois et al., 2014; Purcell, 2012).

Parallels can be drawn here with the concept of the 'metropolis', an increasing focus of post-autonomist writing (e.g. Negri, 2017):

the modern metropolis is to multitude what the factory was to the working class: a primary site for the production of the working class, its internal encounters and organization, and for the expression of antagonism and rebellion (Shukaitis 2016: $55)$.

Negri (2017) looks at the 'metropolis' as a site of resistance as much as of control - "at once a place of exploitation and a terrain of exodus" (108) - exploring how financialised-urban fabrics are central to capital accumulation and newly spatialised subjectivities: "[the] capitalist recomposition of the metropolis builds traces of recomposition for the multitude" (ibid: 30). But while important, too often the 'metropolis' remains nebulous, suffering from a conceptual imprecision that similarly underpins the 'multitude' (see Bowring, 2004). And so, much like the social factory, the frustratingly untapped potential of explicitly geographical autonomist thought is apparent.

A (re)turn to compositional thinking rectifies this, however, as it precisely seeks to avoid hyper-extension and vaguery. Instead detailed analysis can help reveal the opportunities for, and challenges of, resistance that are immanent to different conjunctures. So just as Dyer-Witheford (2008) argues for a compositional analysis of the multitude, a compositional analysis of the social factory ais needed. But to do this and realise the 'treasures which lie within', compositional thinking must move beyond its current aspatiality. Toscano (2004: 198) notes just this, discussing the need for a geographical sensitivity to the key workerist theses of the Copernican inversion and class composition:

it is imperative to begin formulating a truly political topology, one that binds together the subjective forms of political action and the shifting configurations of space. What is required is a thinking of the antagonistic...production of space, not just an account of 
the heterotopias of resistance or the creative destruction of space that accompanies capitalist accumulation.

But despite these important points, the work suffers from uncritical spatial analysis. The quotation alludes to the production of space, yet elsewhere in the paper there is, contradictorily, discussion of 'objective political space'. Further, the work's self-avowed focus is how urban space inflects/affects political compositions; a spatial analysis of class composition. But while necessary, this is insufficient: this paper shows the need for a concomitant (intersectional) class composition analysis of space. And while a focus on the (class) struggles that produce space is nothing new (cf. Lefebvre, 1991), consolidating the fragmented allusions to such processes within autonomist writing is important, bringing with it the tools and benefits of a compositional approach. The paper, therefore, now explores the concept of 'spatial composition' (cf. Gray, 2015, 2018).

Spatial composition and the socio-spatial dialectic

As capitalism becomes increasingly urbanised, through capital switching and the role of rent in a financially-expanded extractivism (Gago, 2017), urban fabrics are key to capitalism. Thus, as the 'metropolis' and 'social factory' only gain greater salience, there is a need to explore how capital constructs urban space to, among other things, maximise accumulation (Gray, 2015). Accordingly, it is possible to conceive of a technical spatial composition, and trace shifts in this across time. As the autonomist architect Tafuri notes (1987: 8):

the construction of a physical space is certainly the site of a 'battle': a proper urban analysis demonstrates this clearly. That such a battle is not totalizing, that it leaves borders, remains, residues, is also an indisputable fact.

But crucially analyses of technical spatial composition must be coupled with the spatial composition of class immanent to them: a political spatial composition. Political spatial compositions are therefore the types of urban struggle that emerge from specific technical spatial compositions, and these can contribute to both the de- and re-composition of class. ${ }^{3}$

\footnotetext{
${ }^{3}$ Return to the urban, community-territorial struggles in Italy mentioned above for clear examples of a recomposition driven by a spatial composition, that itself emerged from a new technical spatial composition (Gray, 2018)
} 
But again, as illuminating as these concepts are, their real explanatory power is their open, dialectical relationship.

Developing this further, just like technical class compositions, technical spatial compositions are not neutral. New technical class compositions emerge to maximise accumulation, but to also discipline labour (Woodcock, 2017). Technical class compositions therefore reflect prior (intersectional) class struggles, as do technical spatial compositions. Two examples prove illustrative. First, Davis (2006) discusses 'Fortress LA', a carceral city where bodies are punitively controlled through a destruction of public space. CCTV and private security support racist policing, while smaller-scale issues like anti-rough sleeping benches combine with large panoptic architecture. This "deliberate socio-spatial strategy" (ibid: 229) emerged in response to rioting, illustrating that new technical spatial compositions are about control as much as accumulation.

Second, shifts in technical spatial composition serve a dual-strategy. Focusing on Paris's Haussmannisation, Harvey (2012) shows how these grand works helped absorb surpluses of labour and capital, but were also (erroneously) thought to avert unrest, with wide boulevards to simultaneously hinder barricades and help the movement of cannon. But rather than prevent urban protest, Haussmannisation, and its continued impact, lead to the emergence of different political spatial compositions, for examples the Paris Commune and the struggles in May 1968. The response, however, has been a continued "bourgeois conquest of central Paris" (ibid: 17). As working-class and immigrant populations/neighbourhoods have been destroyed, ejected, and rebuilt in banlieues, major urban conflict is increasingly bounded (Enright, 2016), a socio-spatial strategy to contain "uprisings and mayhem in those isolated suburbs within which the marginalized immigrants and unemployed workers and youth are trapped" (Harvey, 2012: 17). Consequently, the state uses such uprisings to justify further (racialised) 'territorial stigmatisation' of the banlieues, contributing to their underfunding and neglect in a horribly vicious cycle. Similar processes can be witnessed in 'informal' settlements across the globe which, far from marginal, are increasingly central to capitalism's reproduction, something explored in detail below.

But fundamental to autonomist thought is rejecting analyses of capital as omnipotent. Returning to the Copernican inversion, new technical compositions may emerge in response to militant political compositions, but they always reflect antagonistic relationships between 
capital and labour, as Tafuri's quotation (above) emphasises. A strong, recomposing working class forces better concessions from capital, witnessed in the Fordist compromise. However, as shown by Fordism's decline, these compromises are always uncomfortable, emphasising capitalism's dialectical, contradictory nature. Similar concessions can be seen within technical spatial compositions (for example the building of social housing in post-war Britain ${ }^{4}$ ), illustrating that technical class/spatial compositions are not solely the preserve of capital. Accordingly, technical spatial compositions are contested and the epicentre of both accumulation and resistance (Harvey, 2012).

Spatial compositional thinking therefore contributes to debates on openly dialectical (urban) geographical thinking and the production of space (see Charnock, 2010, 2014), by bringing an autonomist approach to a socio-spatial dialectic:

[t]he structure of organized space [technical spatial composition] is not a separate structure with its own autonomous laws of construction and transformation, nor is it simply an expression of the class structure emerging from the social (i.e. aspatial) relations of production. It represents, instead, a dialectically defined component of the general relations of production, relations which are simultaneously social and spatial. (Soja, 1980: 208)

But beyond just production, complementing important insights from autonomist feminists (e.g. Federici, 2012), spatial composition foregrounds capital's reproduction and circulation, as seen with the social factory. As Mohandesi and Teitelman argue (2017: 52):

social reproduction [is] not just a terrain of struggle; it...[is] a site of class recomposition. Through struggles over social reproduction...different sectors of the...working class beg[in] to articulate themselves into a broader class unity... Although the process [is] uneven and fraught with contradictions, social reproduction....bec[omes] a primary site of class formation...It [is] in neighbourhoods, apartments buildings, parks, schools and streets that the working class ma[kes] itself into a political subject.

\footnotetext{
${ }^{4}$ However, such technical spatial compositions can also be understood as capital's longer-term strategy. Not only can they help provide the conditions for healthier, more efficient labour-power, but in the combined emergence of suburban housing and mortgages in the USA insidious, long-term forms of challenging militancy are present.
} 
This paper therefore emphasises that spatial "compositional rethinking [allows] a consideration of historic urban struggle as systematic and immanent to the tendencies of capital accumulation, rather than a mere anomaly rising intermittently between primary labour struggles" (Gray, 2015: 246). But with its commitment to intersectionality and focus on social reproduction, spatial compositional thinking represents a "properly critical theory of urbanization" as it does not "set up binaries between economic exploitation and social differentiation, but rather expose[s] their coextensive nature" (Jefferson, 2018: 6).

The theoretical benefits of spatial composition analysis are clear: it combines the most powerful of contemporary urban geographical insights into a single, expansive-yet-clear, framework. But there are no universally successful spatial strategies, and compositional thinking makes no claims to absolutes. Rather, it emphasises the need for detailed empirical analysis of specific conjunctures by placing these within historical context. Emergent (spatial) resistance can come from unexpected sources, but however "contingent, complex, and indirect" connections may seem, there is always a "fundamental link [...] between socio-spatial conditions and political practices" (Enright, 2016: 2). Spatial composition analysis clarifies these shifting, yet immanent 'political topologies' (Toscano, 2004), providing a powerful historical/periodising heuristic. But compositional thinking's commitment to militant praxis also makes it forward-looking. Autonomists' initial motivation was to locate capital's weak points and develop effective political strategies to target these - they never took categories for granted, instead forging them, heretically, through workers' enquiry and struggle. The ideas of political and technical class compositions emerged accordingly and provided a clear framework that avoids capital-centric analyses. Technical and political spatial compositions serve the same purpose: gain an understanding of the social factory's technical spatial composition to explore the political spatial compositions that aid maximum recomposition.

Good thinking in this vein makes no assumptions about recomposition, never assuming any strategy is inherently more effective than any other. The healthy scepticism of the traditional party and union form found in autonomist Marxism should be transposed, but without lapsing into an uncritical celebration of everything as resistive, an inadvertent consequence of a totally-subsumed social factory (Pitts, 2018). Similarly, lessons must be learned from defeat. Using spatial composition analysis to explore sustained decomposition is therefore as important as examining exciting ruptures (Gray, 2015). Spatial composition 
analysis can therefore provide a framework with which to approach, unpack, and develop the alluring, yet inchoate, social factory.

The next sections thus apply the ideas developed here to Buenos Aires, emphasising spatial composition analysis's powerful capacity. The research presented here draws on nine months of ethnographic fieldwork in Buenos Aires. Alongside 39 semi-structured interviews with a range of activists, researchers, migrants, and 'elites', 'neighbourhood enquiries' (Gray, 2015) unpacked the city's various compositions. This involved extended walk-along interviews, repeated observations, and extensive, neighbourhood-specific secondary and archival research: mixed-psychogeographical approaches which compositionally analyse the social factory (Shukaitis and Figiel 2013).

\section{Composing Buenos Aires}

To develop a deep analysis of technical and political spatial compositions, this section first provides a historical overview of key shifts to Buenos Aires. This enables a clear periodisation of urban struggles, paying careful attention to both de-and re-composition, as a recomposing political spatial composition in one conjuncture may cause decomposition in another. The paper then turns to a detailed analysis of the villas, exploring how these 'informal' urban settlements perpetuate and resist capitalism. Consequently, the value in autonomist analyses of cities is highlighted (Gray, 2015; Vasudevan, 2015)

Birth of the villas, dictatorship, and slum clearance

The villas first emerged from the largescale, internal rural-urban migration to Buenos Aires in the 1930s, growing 'informally' with migrants, unable to find affordable housing, occupying areas of unused land (Gutierrez, 1999). As rural-urban and neighbouring migration increased steadily, the villas grew, and by 1977 there were 224,885 villeros in the federal capital, and over 1.5 million in the conurbano (urban periphery), a significant proportion of Argentina's then 26.89 million people (Libertun de Duren, 2008). Increasingly the villas were seen as Peronist barrios (neighbourhoods), and the dictatorship in power between 1976 and 1983 therefore viewed them as a great threat. Starting on 13 July 1977, a concerted 'slum clearance' called the Plan Integral de Erradicación was undertaken. Initially the dictatorship claimed the project's main aim was to build a series of motorways, which required the relocation of large villas. The Plan Integral was, however, a key part in Buenos Aires's radical 
restructuring to create 'the right city' (Libertun de Duren, 2008) which was deemed impossible with the presence of 'uneducated' and 'uncivilised' villeros (García, 2008). Driven by class prejudice, racism, stigma, and stereotypes, the plan led to the removal of 208,763 people from the federal capital across four years (Bastia, 2003), the majority of which were relocated to the conurbano (Silva and Schuurman, 1989). Through the construction of a new motorway network the dictatorship (re)produced and strengthened the border between the federal capital and the conurbano (Grimson, 2008). Together, this purging of the villeros and dramatic shifts to the technical spatial composition caused significant and rapid class decomposition.

Post-dictatorship: democratisation, neoliberalism, and fragmentation

After the dictatorship's defeat in 1983 , only $2.5 \%$ of the federal capital's pre-dictatorship villeros remained, and although they returned very quickly (by 1986 eleven villas were home to 19,400 people) most villas nevertheless remained in the conurbano (Silva and Schuurman, 1989). Democracy's return brought significant changes to Buenos Aires, but urban poverty and inequality remained. However, Menem's presidency from 1989 onwards had even more significant impacts. The culmination of the dictatorship's neoliberal approach (Dinerstein, 2002: 14), Menem's policies emphasised privatisation, deregulation, the dismantling of the welfare state, and flexible labour (Wylde, 2011). Unions were weakened and, combined with growing unemployment, the proportion of families below the poverty line grew from $16 \%$ in 1991 to 37\% in 1999 (Gonzalez-Rozada and Menendez, 2002).

These economic policies produced "a novel geography of social inequality" (Libertun de Duren, 2008: 123), as 'public' space became privatised and securitised (Grimson, 2008), creating a 'neoliberal territory' (González, 2010). This disproportionately affected the lives of migrants and the urban poor, for whom parks and other 'public' spaces were the only options for socialising (Lederman, 2013). The government's laissez-faire attitude meant that $80 \%$ of foreign direct investment went to the city's north (Ciccolella, 1999), exacerbating the north/south divide. Rising rents and land costs within the Autonomous City of Buenos Aires (Ciudad Autónoma de Buenos Aires or CABA as it became in 1994) forced people out, again driving population growth in the conurbano (Stratta and Barrera, 2009). But villas also grew within CABA during this period: the number of villeros within CABA was estimated at 2,500 at the dictatorship's end, by 1991 it was 50,900, and by 1999 it had reached 86,666 (Auyero, 
1999). This growth was partly driven by 'territorial purification', whereby people deemed unsuitable for certain barrios were forcibly removed (González, 2010). This process complemented/facilitated gentrification during the 1990s, ultimately forcing more people into the villas/conurbano, while causing an unprecedented rise in gated communities, especially in the north of Buenos Aires Metropolitan Area (BAMA) (Thuillier, 2005). This postdictatorship period therefore created an extremely fragmented, polarised city where growing inequality was territorialised. The growth of both villas and gated communities increased tensions between respective inhabitants, as their separation and lack of integration created a self-fulfilling, discriminatory relationship, based on a fear and dislike of an unknown 'other' (Roitman and Phelps, 2011).

Menem's harsh neoliberal policies continued the decomposition witnessed under the dictatorship. The technical spatial composition of this period created animosity between and within classes. Hand-in-hand were clear attempts to fragment Argentina's historically strong, yet paternalistically-unionised, working class. It worked. Following sustained deindustrialisation and liberalisation, by 1998 over $40 \%$ of the workforce was precariously un(der)employed (Portes and Hoffman, 2003). But while this had a devastating impact on poverty, it birthed new subjectivities such as the unemployed piqueteros (named after their use of road pickets). Unable to strike, the piqueteros recognised the city as crucial to capitalist (re)production, finding power in the metropolis by disrupting 'just-in-time' production (MTD Solano and Colectivo Situaciones, 2002). This group emerged from a sustained period of spatial and class decomposition, caused by the punitive technical spatial/class compositions of the time, reiterating the incomplete power of technical (spatial) compositions and the immanence of political (spatial) compositions. Borne of a specific socio-spatial conjuncture, the piqueteros' spatial politics morphed into the powerful recomposing force explored below. Parallels can also be drawn with the worker-run, recuperated factory movement (Lavaca, 2007). The state-led deindustrialisation was a clear challenge the organised working class, with a clear, uneven spatiality, but from this the conditions for factory/workplace occupations and related autogestive experiments appeared (Trigona, 2014). 
The Argentinazo and the Unemployed Workers' Movements

As the Menem-induced poverty, unemployment, and inequality grew, the inextricably linked spatial fragmentation continued. Things peaked on December $19^{\text {th }}, 2001$, when Buenos Aires saw two days of insurrection, followed by five presidents across fifteen days. Known as the Argentinazo, this period has been explored in depth elsewhere (e.g. Dinerstein, 2002), thus the focus here is instead the spatial compositions it produced. Famously many asambleas (neighbourhood assemblies) emerged in its wake, featuring the reclamation of erstwhile public spaces by porteños (people/things from Buenos Aires). Asambleas were also scaled-up with city-wide discussions (Sitrin, 2006), illustrating the political spatial compositions' immanence and ability to drive class recomposition. Previously antagonistic groups such as the piqueteros and middle-class porteños united under the inclusive, explicitly territorial/territorialising subjectivity of 'vecino' (neighbour) (Sitrin, 2012), reversing, however temporarily, the polarising and fragmenting effects/affects of previous technical spatial compositions.

By now the 'Unemployed Workers' Movement' ('Movimiento de Trabajadores Desempleados' or MTDs) borne of the piqueteros had grown (Mason-Deese, 2016). Focused predominantly in poor barrios and the villas, these organisations moved beyond the piquetes' transient territorialisation (MTD Solano and Colectivo Situaciones, 2002), realising everyday revolutions (Sitrin, 2012). Emphasising social reproduction, horizontalism, and autonomy (Mason-Deese, 2016), these 'territories in resistance' (Zibechi, 2012) were political spatial compositions emerging in-against-and-beyond specific technical spatial compositions. These movements adopted the slogan 'the neighbourhood is the new factory'. Containing a double meaning, this emphasised that, with production embedded within the metropolis, classstruggles must likewise circulate throughout the neighbourhood (Mason-Deese, 2012: 4), a Trontian reading of the social factory. Forging bonds with the expanding recuperated factory movement, the MTDs drove class recomposition in the early 2000s, and it is worth exploring their spatial composition in more depth.

Despite barrio-specific activity, MTDs were/are underpinned by relational territorialities (Clare et al., 2018). The state-abandonment driving their emergence and focus on autonomous social reproduction meant that, although MTDs and the specific challenges 
they faced were localised, their experiences resonated widely, allowing strong links to develop across the city and country. MTDs were/are a broad church, with an inclusive understanding of 'the unemployed' (Mason-Deese, 2016) and containing (often uncomfortably) a range of political currents (Rossi, 2017). The strongest, most militant MTDs were, however, in neighbourhoods where the state tended to be least powerful; where the technical spatial composition was least disciplinary. With these neighbourhoods being mostly located on the southern edge of CABA and in the conurbano, the MTDs found collective power by blockading the major bridges linking the two areas, threatening the circulation of capital throughout the metropolis. Such protests belied an awareness of the weaknesses in Buenos Aires' technical spatial composition and were thus met with state repression.

This post-Argentinazo period illustrates varied spatial repertoires. Militant, diverse, yet united political (spatial) compositions fostered sustained recomposition in the wake of decades of decomposition caused by (in)direct state lethality. The autogestión described above produced new spaces, subjectivities, and forms of politics (Trigona, 2014), a clear sociospatial dialectic. But caution is required to avoid simplistic, overly romanticised/fetishised analyses. The MTDs emerged predominantly out of necessity and were often focused on survival, the recuperated factory movement remains small, and the asamblea movement weakened and (re)produced problematic social relationships, excluding the popular classes once again (Rossi, 2017). The flourishing of these political spatial compositions was immanent to a specific technical spatial composition, typified by fragmentation and inequality. As new technical spatial compositions emerged, in part designed to combat militant and threatening political spatial compositions, the conjuncture changed. Thus, although it improved many middle-class porteños' lives, the 'recovery' described in the next section forced the retreat of the MTDs into smaller areas, contributing to insularity.

\section{'Recovery' and decomposition}

Immediately the 'recovery's' elite-led nature must be flagged. Despite impressive statistics between 2003 and 2007 the economy grew by $9 \%$ a year, unemployment fell from above $20 \%$ to below $9 \%$, and the poverty rate almost halved from around $50 \%$ to $27 \%$ (Levitsky and Murillo, 2008: 17) - these were starting from an extremely low base and reflect the oncelarge middle classes re-finding their feet. Accordingly, the pre-crisis socio-economic realties of a fragmented, racially-striated city and class structure persisted - in the post-crisis 
'recovery' decade, residents of both BAMA's gated communities and villas grew by $50 \%$ (Benwell et al., 2013).

The 'recovery's' effects were felt most keenly within CABA, with increasingly violent gentrification (Rodríguez and di Virgilio, 2016). CABA's average rents increased rapidly postcrisis, from $\$ 12.7 / \mathrm{m}^{2}$ in 2001 , to $\$ 82.5 / \mathrm{m}^{2}$ a decade later (Gobierno de la Ciudad Autónoma de Buenos Aires, 2017: 19-20). The crisis's economic impact must be factored in here, again creating an unnaturally low base, but the trend has only worsened, with average rents now $\$ 224.1 / \mathrm{m}^{2}$ (ibid). Faster and higher than rises in both wages and inflation, these rent increases squeezed CABA's population, contributing to a serious housing crisis (Benwell et al., 2013). This crisis was/is most acute in CABA's south. Historically the poorest area, home to large migrant populations, many villas, and the strongest MTDs, southern barrios have witnessed rent increases over 1500\% between 2001 and the present day (Gobierno de la Ciudad Autónoma de Buenos Aires, 2017: 25). Large numbers of people were thus forced into the conurbano and/or villas, the consequences of which are explored below. Dovetailing maliciously with this gentrification was the interelated privatisation, securitisation, and whitening of the city (Clare, 2015). Changes to the urban fabric went hand-in-hand/glove with the eviction of poor, racialised, and migrant populations. A combination of disciplinary architecture, private security, and the city police then maintained the desired order. Witnessed here, therefore, is an intersectional technical spatial composition: shifts were made to maximise capital accumulation, while simultaneously limiting resistance and (re)producing whiteness (Gordillo, 2016).

CABA's gentrification played a major role in reducing the number and strength of MTDs. Not only were many movement members evicted/ejected, but as previously deindustrialised areas 'redeveloped', the technical spatial compositions from which the MTDs emerged morphed. Spatial shifts thus combined with economic recovery and limited the MTDs' influence. Exacerbating this was a complex constellation of political activity that brought together multitudinous 'bottom up' and 'top down' strategies. At a national and provincial level the Kirchner administration sought to co-opt the MTDs via territorial reincorporation', while at a city level the right-wing Mauricio Macri (then mayor, now president) was more explicitly repressive (Rossi, 2017). Accordingly there were fewer areas of CABA where MTDs were active, with their presence increasingly in the villas and 
conurbano. This shifting technical spatial composition therefore contributed to class decomposition, with previous political spatial compositions no longer effective.

\section{The 'informal' metropolis: migration, the villas, and decomposition}

This section now focuses on CABA's villas in detail, showing how they are a vital metropolitannode. Their technical spatial composition is, however, contributing to decomposition by pitting migrant groups against each other - here the social factory is more a site of control than resistance. This section therefore recognises that (spatial) compositional praxis requires sanguine, intersectional analyses of decomposition (Gray, 2015).

The gentrification forcing people into CABA's villas has created a housing crisis within them, and with dangerous overcrowding, the pressure on housing means rents are often now higher than in 'formal' barrios (Clare, 2015). For those precariously and 'informally' employed, however, villas remain the only option given the lack of requirement for documentation, bank accounts, and deposits (Bastia and Montero Bressán, 2018). The 'formal' and 'informal' housing crises are thus mutually constitutive, with disproportionate impacts on the poor and, especially, migrants. In response, migrants are increasingly reliant upon kinship networks (Benwell et al., 2013). But while this ameliorates short-term issues, these networks contribute to migrant ghettoisation, with different villas and their sub-sections increasingly associated with specific migrant groups - typically Paraguayans, Bolivians, and Peruvians. This point was made by Daniel, an urban researcher and NGO activist:

The formation of...'ethnic neighbourhoods'...has positive elements but also many negative issues. [Migrants] have to pay additional premiums to live on their own, there are issues of discrimination, there are issues concerning ghetto [creation] when these neighbourhoods where ethnicity is a central feature [emerge]...There are neighbourhoods that correspond to specific populations. These ethnic neighbourhoods...are entrenched in different areas of Buenos Aires.

Migrants mentioned that although this creation of 'ethnic neighbourhoods' was often beyond their control - with the only possibilities for housing coming from within kinship networks it was also a preference. Given the everyday racism and discrimination facing migrants (Clare, 2015) respite is invaluable, and the 'positive elements' Daniel describes come from 'ghetto formation'. These 'ethnic neighbourhoods' are especially important for recent arrivals to 
Buenos Aires likely lacking in contacts and capital, and for whom cultural differences are starkest - for examples one young, recent Bolivian migrant told me that the only time he felt comfortable and relaxed was within specifically Bolivian barrios. But by turning inwards levels of animosity between migrant groups increases (Bastia, 2015). National and ethnic differences are (re)produced territorially, and thus naturalised. And this happens at a subbarrio level as well, with individual blocks in villas associated with different migrant groups as one migration activist put it "[even] within barrios [migrants] don't really relate to each other". This is something that Gabriel, a paraguayan migrant living in one of the largest villas echoed: "while there are always things to differentiate between national groups, for me the social question has most to do with where you live". The housing crisis-induced political spatial composition of migrant groups therefore may strengthen the 'social composition' (Notes from Below, 2018) of individual migrant collectives, but the insular spatial politics borne of the villas' technical spatial compositions causes wider class decomposition. The dialectic between class and spatial compositions is thus evident within the villas, but, given the importance of national and ethnic striations, compositional analyses must be intersectional.

Daniel's quotation makes another important point, the idea of a 'migrant premium'. Such is the pressure on housing, and given the combination of their desire to, and their inability not to, live in 'ethnic neighbourhoods', migrants pay more for less, something Mayra, a Bolivian activist, explained:

Villas...have practically no paved roads [or] pavements, however the property is much more expensive than in [middle-class neighbourhoods]. Do you understand why? Because they say "Ah no, Bolivians will pay whatever...to live inside a ghetto" and so they can charge like that.

Most obviously this exacerbates migrant precarity, given low/irregular wages and remittances. But it is also important to consider who receives these extra rents. With the 'informal', kin-based nature of the villas, migrants' rent goes to landlords who are compatriots. This creates an exploitative relationship of reliance within migrant groups, intensifying pre-existing national divides. Crucially though, it also obfuscates class divides within migrant groups, most visible in the Bolivian community. To unpack this it is important to explore the interplay between Bolivian technical class and spatial compositions. 
It is estimated that almost $80 \%$ of 'working age' Bolivians in Buenos Aires work in talleres clandestinos (clandestine textile workshops) - well over 300,000 people across 30,000 talleres (Gago, 2017). These workshops tend to be small enterprises with a handful of families working (and often sleeping and living) in individual dwellings, the consequences of which are manifold. First, for those whose entire lives centre around these individual buildings, there is no clear distinction between the work and domestic sphere, giving great power to joint workshop-owners/landlords. Second, migrants who do live elsewhere typically rent from the cabal of workshop-owners, rendering them still vulnerable and perpetuating the blurry line between work and home. Third, such clandestine, fragmented workshops are an intentional socio-spatial strategy: keeping the workforce hidden and divided limits possibilities for largescale organising, and insulates workshop-owners from the widespread shutting-down of talleres. The technical class and spatial compositions of the Bolivian community are therefore inextricably linked, existing to both reduce militancy and maximise accumulation - through rent and production (ibid). The talleres are also a prime, and at times extreme, example of a disciplinary social factory, where real limits are placed on political and social compositions, within, outside of, and in the liminal spaces between, work. Such is the power of workshop owners, therefore, that they position themselves as guardians of Bolivian life in Buenos Aires (Montero, 2011), exerting an explicitly spatial control over workers. This control includes not only the workplace, but also migrants' periods of social reproduction, powerfully obfuscating marked class divisions within the Bolivian community. Compositional analysis provides a clear way in which to analyse these processes, highlighting that Bolivian migrants' lives (their political and social compositions) are framed by a punitive technical composition that is as spatial as it is intersectional.

Finally it is important to analyse the central role the villas play as nodes in the metropolis's (re)production. CABA's 'deindustrialisation' means that the talleres, many of which exist in the villas, are now the city's third largest manufacturing sector (Montero, 2011: 94). But this is only part of the story. Gago (2017: 171) explores the increasing financialisation of everyday life in the villas, framing this as expanded 'extractivism':

It is necessary to broaden the concept of extractivism beyond its reference to the reprimarization of Latin American economies as exporters of raw materials in order to 
understand the particular role played by territories in the urban peripheries in this new moment of accumulation.

With rising rents in the villas, prospects for accumulation through capital switching increase - with the added incentives that come with owning people's homes and workplaces. Linked to this, much activity in the villas relates to La Salada (Latin America's largest informal market), providing products and workforce. In vivid detail Gago (2017) thus shows how the villas, far from marginal, are central to economic networks at a city, national, and continental scale. In this sense urban fabrics and capital accumulation become increasingly intertwined (Gray, 2015), but, given the villas' 'informality', they provide a view of the metropolis from off the typical (post)autonomist map. And once more, the role of migrants is important here. For many migrants their lives are already financialised before they enter the country, having speculated on their future by paying someone to help them cross the border and locate work and accommodation. These debts tend to be owed to owners of talleres and housing, exacerbating migrant precarity and a panoptic social factory which (re)produces neoliberalism 'from below' (Gago. 2017).

This section has explored CABA's villas in detail. The value of an intersectional, spatial composition analysis has been shown, with its ability to unpack complex processes, thus sharpening the concepts of the social factory. Villas' technical spatial compositions are creating unity within migrant groups, but division between them, ultimately driving class decomposition. Disciplinary technical class and spatial compositions constrain the political and social composition of migrants in the villas in order to maximise accumulation and limit resistance, illustrating a clear socio-spatial dialectic. But technical spatial compositions are as localised as they are temporary, so the paper now explores the conurbano's contemporary composition.

\section{Spatial recomposition?}

While CABA's current technical spatial composition is tending towards decomposition, the situation in the conurbano differs. Although rents and gated communities are increasing (Roitman and Phelps, 2011), housing and 'public' space are less pressurised and securitised. The conurbano's technical spatial composition thus means the migrant ghettoisation in CABA's poorer barrios and villas is less prevalent, as Luis, a Bolivian activist, put it: 
Things are mixed together much more in the conurbano...It is a place that is...thoroughly migrant...[unlike CABA where people] want to be separated from [other] immigrants.

Rather than exacerbating racial and national differences, the conurbano's technical spatial composition aids their transcendence, a point made by Elena, a militant-researcher with an MTD:

In [the conurbano] there are lots of migrants, but people do not...really see those type of [national] categories...There are other categories that become much more important than nationality...like 'unemployed' or being a woman...or being part of that [MTD].

This point was emphasised by Soledad, another MTD activist, who told me that in the conurbano solidarity came "from being there", that it was an "attachment to a place" that mattered more than class or nationality which would often "disappear". Far from the more ghettoised nature of migrant life in CABA, therefore, witnessed here is a more relational form of 'territorial organising' (Clare et al, 2018), emphasising how political spatial compositions can facilitate intersectional class recomposition. But as discussed, compositional analyses look beyond the categories to their dialectical relationship, so this recomposing political spatial composition must be situated, immanently, within the less disciplinary technical spatial composition of the conurbano.

Consequently, the conurbano contains the strongest, most active MTDs (MasonDeese, 2016). These prefigurative 'territories of resistance' (Zibechi, 2012) represent another side of the social factory: resistance and not just control. The conurbano's popular economy, with worker-run enterprises, barter networks, and neighbourhood-level socially-reproductive struggles (Sitrin, 2012), provides examples of explicitly-spatial, recomposing politics (cf. Gray, 2018). Relatedly, factories and their unions in the conurbano now reach out to local neighbourhoods to strengthen their position. Research shows that unions without neighbourhood links are struggling, while those spatially embedded witness renewal and thus recomposition (Elbert, 2015): not only is the neighbourhood the new factory, but successful unions now ensure factories incorporate neighbourhoods. 
It is important to avoid binarised and over-simplified analyses, however. Compositional thinking shuns static absolutes, emphasising the dialectical, dynamic, and incomplete. Just as seemingly omnipotent technical compositions contain cracks and weaknesses, political compositions' recomposing powers are always in tension. Despite being home to radical socio-spatial experiments, the conurbano experiences clear territorial contestation between movements, the state, and capital (Clare et al., 2018). Its popular economy is a 'motley', driving the further financial penetration of 'informal' sectors and settlements and neoliberalism's (re)production 'from below' (Gago, 2017). And there are also clear class-, national-, and party-tensions within MTDs (Rossi, 2017) which the spatial politics described above may be able to mask, but can rarely solve. In fact despite talking about the 'disappearance' of national categories, Soledad also mentioned that Bolivian migrants in the conurbano still come "under attack" from other groups, and are having to increasingly turn inwards to protect themselves, replicating behaviour in CABA. So CABA and the conurbano should thus be understood relationally, as a dialectical metropolis which, while facilitating the extraction of surplus-value and bare reproduction of surplus populations, is also vital locus of struggle. The social factory thus facilitates control and resistance; de- as well as recomposition.

These examples emphasise the socio-spatial dialectic's importance. They also illustrate the need for fine-grained spatial composition analyses that examine both technical and political spatial compositions, at a range of scales, linked to a range of actors, and with a commitment to intersectionality. Across Buenos Aires we are witnessing simultaneous deand re-composition, with political spatial compositions that prove effective in the conurbano often unworkable in CABA. Radical spatial politics still exist in Buenos Aires, yet are mutating and particular to specific conjunctures and technical spatial compositions.

\section{Conclusions}

The idea of class composition is one of autonomist Marxism's lasting legacies. It provides a framework to analyse evolving forms of struggle and repression, exploring how these can lead to both re-and de-compositions. But despite odd fragments, the ideas remain fundamentally aspatial. Although Toscano (2004) notes that spatial ideas need to be applied to class composition analysis, this paper goes further, also applying the ideas of class composition to 
space. By developing the idea of technical and political spatial compositions the paper therefore makes a clear and important contribution to autonomist thought. However, it does more than just this. The move to post-autonomist thinking comes with a yet more latent spatiality, most obviously in the case of the metropolis and the extended use of the social factory. But while these concepts allude to important geographical issues they remain vague, belying post-autonomism's proclivity towards the generalising (Pitts, 2018; Wright, 2017). In this sense a (re)turn to autonomist concepts, once spatialised and intersectional, can save elements of post-autonomism from themselves (Bellofiore and Tomba, 2017; de Bloois et al, 2014). Compositional analyses provide a rigorous, grounded, and clear framework with which to understand socio-spatial dialectics, thus helping to deliver on the promises of the social factory. There is therefore an obvious synergy to an emergent autonomist geography: geographical analysis sharpens the autonomists' best tool, while compositional thinking is perfect for approaching issues in contemporary (urban) geography. This paper therefore argues that the broader trend of autonomous geographies (e.g. Pickerill and Chatterton, 2006; Merrifield, 2011; Vasudevan, 2015) would be best serviced by a (re)turn to autonomist ideas.

Using this original framework, the paper also makes an original empirical contribution to studies of Buenos Aires. The periodising value of compositional thinking has been shown, shedding light on the ebb and flow of Buenos Aires' spatial politics, with new political spatial compositions emerging, immanently, from prior technical spatial compositions. Although novel forms of resistance are apparent, the disciplinary and accumulative nature of the social factory has been shown through analyses of mutating technical spatial compositions. More than just a periodising heuristic, however, spatial composition analysis retains the autonomist Marxist commitment to praxis: it is a tool to understand the contours, strengths, and weaknesses of specific spatial conjunctures. This paper does this through a focus on migrants in the villas and/or conurbano. With the former, migrant ghettoisation is a serious hindrance to recomposition and shows how non-class identities/structures intersect to influence political class and spatial compositions. Whereas, the technical spatial composition of the latter affords clearer avenues for recomposition through relational territorial organising. In these cases we therefore see the dual meaning of the social factory thesis, with expanded potentials for control as much as resistance. The paper therefore expands on Gago's (2017) pathbreaking work on the role of migrants and 'informal' urban settlements in a period of 
financialised-extractivism, showing how migrants are simultaneously contesting and (re)producing neoliberalism 'from below'.

Spatial composition provides a framework with which to analyses these myriad complex processes, a proper understanding of which is vital for radical praxis and recomposition. This paper therefore highlights the importance of carrying out spatial composition analyses at a range of scales, as examples of re-and de-composition can coexist, while also reiterating the need for (spatial) compositional analyses to be intersectional. The power of the spatial composition framework, however, is its transferability. A focus on Buenos Aires and its 'informal' settlements helps move (post)autonomist thinking outside of its Eurocentric comfort zone (cf. Campbell, 2018; Gago, 2017; Luisetti et al., 2015, Marks, 2012), developing its explanatory potential in the process. Spatial composition analysis therefore can and should be applied to other cities, helping an autonomist geography to first coalesce, and then move beyond itself to realise the treasures that lie within.

\section{References}

Auyero J (1999) 'This is a Lot Like the Bronx, isn't it?' Lived Experiences of Marginality in an Argentine Slum. International Journal of Urban and Regional Research, 23(1):45-69.

Bastia T (2003) Urbanización, migración y exclusión social: viñetas desde las villas miseria. Papeles (87):83-91

Bastia T (2015) Transnational migration and urban informality: Ethnicity in Buenos Aires' informal settlements. Urban Studies, 52(10):1810-1825.

Bastia T and Montero Bressán J (2018) Between a guest and an okupa: Migration and the making of insurgent citizenship in Buenos Aires' informal settlements. Environment and Planning A: Economy and Space, 50(1):31-50.

Battaggia R (1981) Operaio massa e operaio sociale: alcune considerazione sulla "nuova composizione di class". Primo Maggio 14.

Bellofiore R and Tomba M (2017) Afterword. In: Wright, S Storming Heaven: Class Composition and Struggle in Italian Autonomist Marxism, London:Pluto, 237-249.

Benwell MC, Haselip J and Borello JA (2013) Housing, Security, and Employment in PostNeoliberal Buenos Aires. Latin American Perspectives 40(2):146-167.

Bologna S (2007) The Tribe of Moles. In: Lotringer S and Marazzi C (eds), Autonomia: Postpolitical Politics, New York:Semiotext(e):36-61. 
Bowring, F., (2004). From the mass worker to the multitude: A theoretical contextualisation of Hardt and Negri's Empire. Capital \& Class, 28(2):101-132.

de Bloois J, Jansen M and Korsten FW (2014) Introduction: From Autonomism to PostAutonomia, from Class Composition to a New Political Anthropology? Rethinking Marxism 26(2):163-177.

Camfield D (2004) Re-Orienting Class Analysis: Working Classes as Historical Formations. Science \& Society, 68(4):421-446.

Campbell, S., 2018. Anthropology and the social factory. Dialectical Anthropology:1-13. Published online. https://link.springer.com/article/10.1007/s10624-018-9498-5

Charnock, G., (2010). Challenging New State Spatialities: The Open Marxism of Henri Lefebvre. Antipode, 42(5):1279-1303

Charnock, G., (2014). Lost in Space? Lefebvre, Harvey, and the Spatiality of Negation. South Atlantic Quarterly, 113(2):313-325

Ciccolella P (1999) Globalización y dualización en la región metropolitana de Buenos Aires. Grandes inversiones y reestructuracción socioterritorial en los años noventa. EURE, Santiago 25(76):5-27.

Clare N (2015) Territory, intersectionality, and class composition: 'Neighbouring migrants' in Buenos Aires. Unpublished PhD thesis. University of Sheffield.

Clare N, HabermehI V and Mason-Deese L (2018) Territories in contestation: relational power in Latin America. Territory, Politics, Governance 6(3):302-321

Cleaver H (2000) Reading capital politically. Oakland:AK Press.

Davis M (2006) City of Quartz: Excavating the Future in Los Angeles. London:Verso.

Day RE (2002) Social capital, value, and measure: Antonio Negri's challenge to capitalism. Journal of the American Society for Information Science and Technology, 53(12):10741082.

Dinerstein AC (2002) The battle of Buenos Aires. Crisis, insurrection and the reinvention of politics in Argentina. Historical Materialism, 10:5-38.

Dyer-Witheford N (2008) For a Compositional Analysis of the Multitude. In: Bonefeld W (ed.), Subverting the Present, Imagining the Future: Insurrection, Movement, Commons, New York:Autonomedia.

Elbert R (2017) Union Organizing after the Collapse of Neoliberalism in Argentina: The Place of Community in the Revitalization of the Labor Movement (2005-2011). Critical Sociology, 43(1):129-144. 
Enright T (2016) The political topology of urban uprisings. Urban Geography(4):1-21.

Ferreira FHG, Messina J, Rigolini J, et al. (2012) Economic mobility and the rise of the Latin American middle class. Washington, D.C.:World Bank.

Gago, V. (2017). Neoliberalism from Below: Popular Pragmatics and Baroque Economies, Durham, NC:Duke University Press.

García M (2008) Los orígenes de los barrios precarios en la ciudad. Available at: http://www.solesdigital.com.ar/sociedad/historia villas 1.htm.

Gobierno de la Ciudad Autónoma de Buenos Aires (2017) Mercado Inmobiliario de la Ciudad de Buenos Aires: Precio de oferta de locales en venta y alquiler. Available at: http://www.buenosaires.gob.ar/sites/gcaba/files/locales enero17.pdf

González P (2010) Los asentamientos populares en la Región Metropolitana de Buenos Aires: Emergencia y reproducción del territorio en los procesos neoliberales de construcción de ciudad (1980-2010). Geograficando 6(6):147-164.

Gonzalez-Rozada M and Menendez A (2002) Why have poverty and income inequality increased so much? Argentina 1991-2002. Princeton University.

Gordillo G (2016) The savage outside of White Argentina. In: Alberto P and Elena E (eds), Rethinking Race in Modern Argentina, Cambridge:Cambridge University Press, pp. 241267.

Gray, N (2015) Neoliberal Urbanism and Spatial Composition in Recessionary Glasgow. Unpublished PhD thesis. University of Glasgow.

Gray, N (2018) Beyond the Right to the City: Territorial Autogestion and the Take over the City Movement in 1970s Italy. Antipode 50(2):319-339

Grimson A (2008) The making of new urban borders: Neoliberalism and protest in Buenos Aires. Antipode 40(4):504-512.

Gutierrez JE (1999) La fuerza histórica de los villeros. Buenos Aires:Jorge Baudino Ediciones.

Harvey D (2012) Rebel Cities: From the right to the city to the urban revolution. London:Verso.

Jefferson BJ (2018) Dark side of the planet: hidden dimensions of urban agglomeration. Urban Geography, 1-8. Published online. doi: 10.1080/02723638.2018.1450464

Lavaca (2007) Sin patron: stories from Argentina's worker-run factories. Chicago, II.:Haymarket Books.

Lederman J (2013) 'But this is a park'! The paradox of public space in a Buenos Aires 'no man's land'. Citizenship Studies, 17(1):16-30. 
Lefebvre H (1991) The production of space. Oxford:Blackwell.

Levitsky S and Murillo M V (2008) Argentina: From Kirchner to Kirchner. Journal of Democracy, 19(2):16.

Libertun de Duren N (2008) Intertwining national and urban policies: National development strategies and municipal tactics in greater Buenos Aires. Political Power and Social Theory 19:119-157.

Luisetti F, Pickles J and Kaiser W (2015) Autonomy: Political Theory/Political Anthropology. In: Luisetti F, Pickles J, and Kaiser W (eds), The Anomie of the Earth: Philosophy, Politics, and Autonomy in Europe and the Americas, Durham \& London: Duke University Press, pp:1-21.

Marks B (2012) Autonomist Marxist theory and practice in the current crisis. ACME 11(3):467491.

Mason-Deese L (2012) The Neighbourhood is the New Factory. Viewpoint Magazine (2).

Mason-Deese L (2016) Unemployed Workers' Movements and the Territory of Social Reproduction. Journal of Resistance Studies 2(2):65-99.

Merrifield, A. (2011). Magical Marxism: subversive politics and the imagination, London:Pluto Press.

Mohandesi S (2013) Class consciousness or class composition? Science and Society 77(1):7297.

Mohandesi S and Teitelman E (2017) Without Reserves. In: Bhattacharya T (ed.), Social Reproduction Theory, London:Pluto Press, pp:37-67.

Montero J (2011) Neoliberal fashion: The political economy of sweatshops in Europe and Latin America. Unpublished PhD Thesis. Durham University.

MTD Solano and Colectivo Situaciones (2002) La hipótesis 891. Más allá de los piquetes. Buenos Aires:Ediciones de mano en mano.

Negri, A., (2018). From the Factory to the Metropolis E. Emery, ed., Cambridge:Polity.

Notes From Below (2018). The Workers' Inquiry and Social Composition. Notes from Below(1)

Palazzo, D.P., (2014). The "Social Factory" In Postwar Italian Radical Thought From Operaismo To Autonomia. Unpublished PhD thesis, The City University of New York.

Pasquinelli, M., (2014). To Anticipate and Accelerate: Italian Operaismo and Reading Marx's Notion of the Organic Composition of Capital. Rethinking Marxism, 26(2):178-192. 
Pickerill J and Chatterton P (2006) Notes towards autonomous geographies: creation, resistance and self-management as survival tactics. Progress in Human Geography 30(6):730-746.

Pitts, F.H. (2018). Critiquing capitalism today: New ways to read Marx, Basingstoke:Palgrave Macmillan.

Portes A and Hoffman K (2003) Latin American Class Structures: Their Composition and Change during the Neoliberal Era. Latin American Research Review, 38(1):41-82.

Purcell, M. (2012). Gramsci Is Not Dead: For a 'Both/And' Approach to Radical Geography. ACME: An International Journal for Critical Geographies, 11(3):512-524.

Rodríguez $M$ and di Virgilio M (2016) A city for all? Public policy and resistance to gentrification in the southern neighborhoods of Buenos Aires. Urban Geography 37(8): 1215-1234.

Roggero G (2010) Organized spontaneity: class struggle, workers' autonomy, and soviets in Italy. WorkingUSA, 3(2):201-212.

Roitman S and Phelps N (2011) Do gates negate the city? gated communities' contribution to the urbanisation of suburbia in Pilar, Argentina. Urban studies 48(16):3487-3509.

Shukaitis S (2013) Recomposing precarity: Notes on the laboured politics of class composition. ephemera: theory \& politics in organization 13(3):641-658.

Shukaitis S (2016) The Composition of Movements to Come: Aesthetics and Cultural Labour After the Avant-Garde. London:Rowman \& Littlefield.

Shukaitis S and Figiel J (2013) Metropolitan strategies, psychogeographic investigations. Cultural Studies $\leftrightarrow$ Critical Methodologies 13(6):536-543.

Shukaitis S, Graeber D and Biddle E (2007) Constituent imagination: militant investigations//collective theorization. Oakland:AK Press.

Silva J and Schuurman FJ (1989) Neighbourhood association in Buenos Aires: contradictions within contradictions. In: Schuurman F and Van Naerssen T (eds), Urban Social Movements in the Third World, London:Routledge.

Sitrin M (2006) Horizontalism: Voices of popular power in Argentina. Oakland:AK Press .

Sitrin M (2012) Everyday Revolutions: Horizontalism and Autonomy in Argentina. London:Zed Books.

Soja EW (1980) The Socio-Spatial Dialectic. Annals of the Association of American Geographers, 70:207-225. 
Stratta F and Barrera M (2009) El tizón encendido: protesta social, conflicto y territorio en la Argentina de la posdictadura. Buenos Aires:Editorial El Colectivo.

Tafuri M (1987) The Sphere and the Labyrinth: Avant-Gardes and Architecture from Piranesi to the 1970s. Cambridge, MA:MIT Press.

Thorburn ED (2017) Cyborg witches: class composition and social reproduction in the GynePunk collective. Feminist Media Studies, 17(2):153-167.

Thuillier G (2005) Gated communities in the metropolitan area of Buenos Aires, Argentina: A challenge for town planning. Housing Studies 20(2):255-271.

Toscano A (2004) Factory, territory, metropolis, Empire. Angelaki: journal of the theoretical humanities, 9(2):197-216.

Trigona M (2014) Argentina's Movement Against Austerity and the Politics of Space. In: Shannon D (ed.), The end of the world as we know it? Crisis, resistance, and the age of austerity, Oakland:AK Press, pp. 215-236.

Tronti M (1964) Lenin In England. Classe Operaia 1(1).

Tronti M (1971) Operai e Capitale. Turin:Einaudi.

Vasudevan, A. (2015). Metropolitan preoccupations : the spatial politics of squatting in Berlin, Oxford: Wiley Blackwell.

Woodcock J (2017) Working the Phones: Control and Resistance in Call Centres. London:Pluto Press.

Wright S (2017) Storming heaven: Class composition and struggle in Italian autonomist Marxism. London:Pluto Press .

Wylde C (2011) State, society and markets in Argentina: The political economy of neodesarrollismo under Néstor Kirchner, 2003-2007. Bulletin of Latin American Research 30(4):436-452.

Zerowork Collective (1975) Introduction to Zerowork I. Zerowork 1.

Zibechi R (2012) Territories In Resistance: A Cartography of Latin American Social Movements. Oakland:AK Press. 